\title{
Streptozotosin ile Tip-1 diyabet oluşturulan sıçanlarda acı badem yağının serum ve eritrositlerdeki bazı biyokimyasal parametrelere etkisi
}

\author{
Ersin Demir1, Ökkeş Yılmaz'1
}

ÖZET: Bu çalışma, Tip-1 diyabet oluşturulan sıçanlarda acı badem yağının serum ve eritrositlerdeki bazı biyokimyasal parametreler üzerine etkisinin araştırılması için tasarlandı. Sıçanlar kontrol (K), diyabet (STZ) ve diyabet+acı badem yağı (STZ+ABY) olmak üzere üç grubu ayrıldı. Diyabet gruplarına intraperitoneal enjeksiyonla streptozotosin (65 mg/kg) verilerek diyabet oluşturuldu. Acı badem yağı grubundaki sıçanlara haftada iki gün $1 \mathrm{ml} / \mathbf{k g}$ dozunda intraperitoneal enjeksiyonla acı badem yağı, ayrıca deney boyunca toz haline getirilmiş 2 gr acı badem çekirdeği, 500 ml içme suyuna eklenerek verildi. Kontrol grubuna göre, STZ grubunda postprandial kan glukoz düzeyinin anlamlı olarak arttığı $(p<0.001)$, STZ grubu ile karşılaştırıldığında ise, STZ+ABY grubunda postprandial kan glukoz düzeyinin anlamlı olarak azaldığı $(p<0.001)$ belirlendi. Kontrol grubuna göre, STZ grubunun serum ve eritrositlerinde malondialdehit (MDA) düzeyinin anlamlı olarak arttığı $(p<0.001)$, eritrositlerde ise glutatyon (GSH) düzeyinin anlamlı olarak azaldığı $(p<0.001)$ belirlendi. STZ grubuna göre, STZ+ABY grubunun serum ve eritrositlerinde MDA düzeyinin anlamlı olarak azaldığı $(p<0.001)$, eritrositlerde ise GSH düzeyinin anlamlı olarak arttığı $(p<0.001)$ saptandı. STZ grubuna göre, STZ+ABY grubunun serumunda palmitik ve linoleik asit değerlerinin, eritrositlerinde ise; palmitik, palmitoleik, stearik, araşidonik ve dokosaheksaenoik asit değerlerinin kontrol grubu değerlerine yaklaştığı belirlendi. STZ+ABY grubunda ayrıca serum $\alpha$-tokoferol asetat ve $\beta$-sitosterol düzeylerinin ve eritrositlerde ise $\alpha$-tokoferol düzeyinin kontrol gurubu değerlerine yaklaştığı tespit edildi. Serumda STZ grubuna göre, STZ+ABY grubunda $\alpha$-tokoferol düzeyinin arttığı belirlendi. Sonuç olarak, diyabetik sıçanlara uyguladığımız acı badem yağının serum ve eritrositlerde, lipid peroksidasyon, glutatyon, yağ asidi ve $\alpha$-tokoferol düzeyleri üzerinde olumlu etkileri bulunmaktadır. Elde ettiğimiz verilere göre, acı bademin diyabet tedavisinde kullanılmasının iyi bir diyet stratejisi olabileceğini fakat bu çaIışma verilerinin kapsamlı çalışma verileri ile desteklenmesi gerektiğini düşünmekteyiz.

ANAHTAR KELIMELER: Diyabet, streptozotosin, acı badem yağı, lipid peroksidasyon, $\alpha$ tokoferol, yağ asidi kompozisyonu

\section{GiRiş}

Diyabette vücudun antioksidan savunma sisteminin kapasitesinin azaldığı, bu durumun da reaktif oksijen ile serbest radikal türlerinin üretiminde artışa sebep olarak diyabete ait komplikasyonların ortaya çıkması ile gelişmesine zemin hazırladı $\breve{g}_{1}$ kabul edilmektedir (1). Bu nedenle sağlıklı bireylere göre, diyabetli bireylerde göz, böbrek, nörolojik, serebrovasküler, kardiyovasküler ve periferik damar hastalıkları ile ilgili komplikasyonların gelişime risk daha fazladır (2).

Diabetes mellitus, insülin salgılanmasında azalma, insülin aktivitesine direnç veya her iki sebepten dolayı ortaya çıkan kronik hiperglisemiye bağlı olarak karbohidrat, lipit ve protein gibi enerji kaynağı olan moleküllerin
KURUM

1Fırat Üniversitesi, Biyoloji, Elazığ, Türkiye

\section{ILETIŞIM}

Ersin Demir

E-posta:

ersncan.dmr@gmail.com

Gönderilme:

04.11 .2013

Revizyon:

04.11 .2013

Kabul:

04.11 .2013 
metabolizmasında bozulmaların ortaya çıktığı ve dünya genelinde dramatik bir şekilde artma eğilimi gösteren metabolik hastalıktır. Streptozotosin (STZ), pankreasta bulunan ve insülin üreten $\beta$-hücrelerinde oksidatif stres yolu ile hasar oluşturarak bu hücrelerin insülin üretme kapasitesinde azalmaya sebep olarak hiperglisemik bir durumun ortaya çıkmasına neden olan diyabetojenik bir ajandır $(3,4)$. Diyabette hiperglisemi, hücrelere glikoz girişi ile dokuların glikoz kullanımının azalması ve karaciğerde glikoneogenez yolu ile glikoz üretiminin artması sonucu gelişir $(5,6)$.

Badem, gülgiller familyasından olan bir ağacın meyvesidir. Badem yağı, Hint, Çin ve Yunan gibi eski uygarlıklardan bu yana sağlık ve güzellik için kullanılmış ve günümüzde de birçok kozmetik ürününün en önemli ham maddesi durumundadır (7). Acı badem çekirdeklerinin diyabet tedavisinde kullanıldığı ifade edilmiştir $(8,9)$. Badem çekirdeği sahip olduğu tekli ve çoklu doymamış yağ asitleri, tokoferoller ve fenolik bileşikler bakımından önemli bir besin maddesidir. Badem yağının antioksidan aktivite gösterdiği, serbest radikal temizleme kabiliyetinin olduğu, karaciğer hasarının önlenmesi ile tedavisinde önemli sonuçlar gösterdiği ortaya çıkarılmıştır (10). Sahip olduğu bu bileşiklerden dolayı bademin insan sağlığına olan yararlı etkileri yapılan birçok çalışmada ortaya çıkarılmıştır $(10,11)$.

Diyabet, bir oksidatif stres hastalığı olduğu için antioksidan aktiviteye sahip bileşiklerin bu hastalığın tedavisinde olumlu etkileri olabilmektedir. Acı bademin antioksidan potansiyele sahip olduğu ifade edilmektedir (12).

Bu çalışmada acı badem yağının diyabetik sıçanların serum ve eritrositlerindeki MDA, GSH, yağ asidi, kolesterol, a-tokoferol, K vitamini ile bazı steroller üzerindeki etkisinin değerlendirilmesi amaçlanmıştır.

\section{GEREÇ VE YÖNTEM}

\section{Deney hayvanları}

Deneysel uygulamalar, Fırat Üniversitesi Hayvan Deneyleri Etik Kurulu'ndan onay alınarak gerçekleştirildi (Etik karar no: 05.05.2011/81). Bu çalışmada 30 adet 8-10 haftalık Wistar albino irkı erkek sıçanlar kullanıldı.

\section{Deneysel diyabetin oluşturulması}

Sıçanlar kontrol (K, n:10), diyabet (STZ, n:10) ve diyabet+acı badem yă̆1 (STZ+ABY, n:10) olmak üzere rastgele üç gruba dağıtıldı. Diyabet oluşturmak için STZ ve STZ+ABY grubunu oluşturan sıçanlara $65 \mathrm{mg} / \mathrm{kg}$ dozunda streptozotosin (STZ) fosfat-sitrat tamponunda ( $0.1 \mathrm{M}, \mathrm{pH} 4.5)$ çözülerek intraperitoneal enjeksiyonla verildi (13). STZ enjeksiyonundan 72 saat sonra, gece açlığını takiben sıçanların kuyruk veninden kan örneği alınarak glukometre (Smart Chek) cihazında glukoz ölçümleri yapıldı. Bu ölçüm sonucunda, açlık kan glukoz düzeyi $250 \mathrm{mg} / \mathrm{dl}$ veya üstü olan sıçanlar diyabetik olarak kabul edildi (14). Bu çalışma 60 gün sürdü ve çalışmanın sonunda tüm sıçanlar servikal dekapitasyon yolu ile dekapite edildi. Tüm grupların kan örnekleri EDTA'lı tüplere alındı ve tüpler $2790 \mathrm{x}$ g'de $5 \mathrm{dk}$ santrifüj edilerek serum ve eritrosit pelleti bir birinden ayrıldı. Serum örnekleri ayrı deney tüplerine alındı ve analizler yapılıncaya kadar $-86^{\circ} \mathrm{C}^{\prime}$ de saklandı. Eritrosit pelletleri ise \% 0,9'luk $\mathrm{NaCl}$ ile üç kez yıkandıktan sonra buz soğukluğundaki $6 \mathrm{ml}$ Tris-HCl, Trisbase ve EDTA (pH:7,4) tamponu ile homojenize edildi ve sonra $+4^{\circ} \mathrm{C}^{\prime}$ de 9050 x g' de 20 dakika santrifüj edilerek supernatant ve pellet elde edildi. Supernatant kısımdan MDA, GSH ve total protein analizleri, pellet kısımdan ise a-tokoferol, K vitamini, kolesterol, sterol ve yağ asidi analizleri yapıldi.

\section{Bitki ekstraktının hazırlanması}

Acı badem çekirdekleri etüvde kurutulduktan sonra havanda dövülerek toz haline getirildi ve bundan $50 \mathrm{~g}$ alınarak $250 \mathrm{ml}$ $3 / 2$ (v/v) oranında n-hekzan/izopropil alkol karışımı ile blenderde parçalandı ve sonra bu homojenat santrifüj edildi (9050 $x g^{\prime}$ de $+4{ }^{\circ} \mathrm{C}$ ). Santrifüj sonunda elde edilen supernatant rotavapor kullanılarak çözücülerden arındırıldı ve DMSO'da (dimetil sülfosalisilik asit) çözülerek kullanıma hazır hale getirilen acı badem yağ ekstraktı, STZ+ABY grubuna haftada iki gün $1 \mathrm{ml} / \mathrm{kg}$ dozunda intraperitoneal enjeksiyonla verildi, ayrıca deney boyunca toz haline getirilmiş acı badem çekirdekleri (2 gr / 500 ml) içme suyuna eklenerek, sıçanlara bu su verildi (Diyabetik bir sıçan bir günde bu sudan yaklaşık olarak $75 \mathrm{ml}$ kadar tüketmekte ve bu su her gün değiştirilmekte). Bu süre zarfında K ve STZ gruplarına haftada iki gün $1 \mathrm{ml} / \mathrm{kg}$ dozunda intraperitoneal enjeksiyonla DMSO uyguland.

\section{Deneysel prosedürler}

\section{Protein tayini}

Serum ve eritrositlerde protein miktarı Lowry ve arkadaşlarının tanımladığı metoda göre spektrofotometrik olarak ölçüldü (15). Alınan $10 \mu \mathrm{l}$ serum ve eritrosit örneğine lowry çözeltisi eklendi ve 10 dakika beklendi, süre sonunda su ile seyreltilmiş folin reaktifi eklendi ve 30 dakika sonra $760 \mathrm{~nm}$ dalga boyunda örneklerin absorbansları okundu. Sığır serum albümin (BSA) standart olarak kullanıldı.

\section{MDA tayini}

MDA düzeyi Okawa ve arkadaşlarının tanımladı̆̆ı metotta bazı değişiklikler yapılarak spektrofotometrik olarak ölçüldü (16). $1 \mathrm{ml}$ alınan serum ve eritrosit örneği üzerine $0,5 \mathrm{ml} \%$ $8,1^{\prime}$ lik SDS (sodyum dodesil sülfat), $0,5 \mathrm{ml} \% 0.8^{\prime}$ lik TBA (tiyobarbitürik asit), $1 \mathrm{ml} \% 10^{\prime}$ luk TCA (triklorasetik asit), $1 \mathrm{ml} \%$ $20^{\prime}$ lik glasiyel asetik asit ve $50 \mu 1 \% 4^{\prime}$ lük BHT (bütilat hidroksi toluen) eklenerek bu karışım vortekslendi ve sonra 60 dakika kaynar su banyosunda bekletildi. Süre sonunda tüpler oda sicaklığına kadar soğutulduktan sonra $4 \mathrm{ml}$ bütanol/piridin (1:15 oranında) karışımı ilave edildi ve sonra tüpler 1780 x g' de 10 dakika santrifüj edildi. Üsteki organik faz alınarak $532 \mathrm{~nm}$ dalga boyunda örneklerin absorbansları okundu. 1,1,3,3-tetraetoksipropan standart olarak kullanıld1.

\section{GSH tayini}

GSH tayini Elman'nın tanımladığı metoda göre yapıldı (17). Eritrosit örneklerinden $2 \mathrm{ml}$ alınarak üzerlerine $2 \mathrm{ml} \% 10^{\prime} l u k$ TCA ilave edildi ve sonra örnekler $10 \mathrm{dk} 2790$ x g'de santrifüj edilerek protein kısmın çökmesi sağlandı, supernatant kısım başka bir tüpe alındı ve üzerine $1 \mathrm{ml}$ 5,5' ditiobis 2- nitrobenzoik asit (DTNB) çözeltisi (\%1 sodyum sitrat içinde $30 \mathrm{mg}$ DTNB çözülerek hazırlandı) ve $0,3 \mathrm{M} \mathrm{Na}_{2} \mathrm{HPO}_{4}$ (Disodyum hidrojen fosfat) çözeltisinden $2 \mathrm{ml}$ ilave edildi ve örneklerde oluşan sarı rengin absorbansı 412 nm'de okundu. İndirgenmiş glutatyon standart olarak kullanıldı.

\section{Serum ve eritrositlerde lipid kompozisyonu, $\alpha$-tokoferol,} $\mathrm{K}$ vitamini, kolesterol ve sterol tayini

Serum ve eritrosit örneklerinde lipit, a-tokoferol, K vitamini, kolesterol ve sterol ekstraksiyonu Hara ve Radin tarafından 
tanımlanan metoda göre yapıldı (18). Bunun için, serum ve eritrosit örnekleri 3:2 (v/v) oranında hekzan-isopropanol karışımı ile homojenize edildi. Daha sonra bu homojenat santrifüj edilerek elde edilen supernatant kisımdan a-tokoferol, $\mathrm{K}$ vitamini, kolesterol, sterol ve yağ asidi analizleri yapıldı. Yağ asitlerinin gaz kromatografisinde (GC) analizinin yapılabilmesi için metil esteri türevlerine dönüştürülmesi gerekmektedir bunun için Christie'nin ifade ettiği asit katalizörlü esterleştirme metodu kullanıldı (19).

Yağ asidi kompozisyonunu belirlemek için ayrılan örneklerin üzerine \% 2 'lik metanolik sülfürik asitten $5 \mathrm{ml}$ ilave edildi, vortekslenerek iyice karışmaları sağlandı. Bu karışım $55^{\circ} \mathrm{C}^{\prime} \mathrm{de}$ 15 saat metilleşmeye bırakıldı. Süre sonunda, tüpler etüvden çıkarıldı, oda sıcaklığına kadar soğutuldu ve $5 \mathrm{ml} \% 5$ lik sodyum klorür ilave edilerek iyice karıştırıldı. Tüpler içinde oluşan yağ asidi metil esterleri $5 \mathrm{ml}$ hekzan ile ekstre edildi ve hekzan fazı üsten pipetle alınarak $5 \mathrm{ml} \%$ 2'lik $\mathrm{KHCO}_{3}$ ile muamele edildi ve fazların ayrılması için 4 saat bekletildi. Daha sonra metil esterlerini içeren karışımlar, $45^{\circ} \mathrm{C}^{\prime}$ de ve azot gaz akımı altında çözücüleri uçuruldu, $1 \mathrm{ml}$ n-heptan ile çözüldü ve yağ asidi metil esterleri gaz kromatografisinde analiz edildi. Bu analiz için SPTM_2380 kapiller GC kolon (L× ID. $30 \mathrm{~m} \times$ $0.25 \mathrm{~mm}$, df $0.20 \mu \mathrm{m}$ ) (Supelco, Sigma, USA) kullanıld1.

a-tokoferol, $\mathrm{K}$ vitamini, kolesterol ve sterol için alınan serum ve eritrosit örneklerinin üzerine $5 \mathrm{ml} \% 10^{\prime}$ luk $\mathrm{KOH}$ çözeltisi ilave edildi (20). Örnekler vortekslendikten sonra $85^{\circ} \mathrm{C}^{\prime}$ de 15 dakika bekletildi. Tüpler çıkartılarak oda sıcaklığına kadar soğutuldu ve üzerlerine $5 \mathrm{ml}$ saf su ilave edilerek karıştırıldı. Sabunlaşmayan lipofilik moleküller 2x5 ml hekzan ile ekstrakte edildi. Hekzan fazı, azot gaz akımı ile uçuruldu. $1 \mathrm{ml}$ (\% 60+\% 40, v/v) asetonitril/metanol karışımında çözülerek HPLC-UV'de analiz edildi. Mobil faz olarak asetonitril/metanol (\%60+\%40, v/v) karışımı kullanıldı. AnalizdeSüpelcosil LC ${ }^{\text {TM }} 18$ (15x4.6 mm, 5 m; Sigma, USA) kolon kullanıldı (21).

\section{Istatistik analizi}

İstatistiksel analiz için, SPSS 15.0 software programı kullanıldı. Kontrol grubu ile deneysel grupları arasındaki karşılaştırma varyans analizi (ANOVA) ve LSD (En küçük anlamlı fark analizi) testleri kullanılarak yapıldı. Sonuçlar ortalama tstandart hata olarak verildi. İstatistiksel anlamlılık düzeyi için $p$ değeri $p<0.05$ olarak belirlendi.

\section{BULGULAR}

Deneysel tip-1 diyabet oluşturulmuş sıçanların kan glukoz düzeyindeki değişim Tablo1'de gösterilmiştir. STZ enjeksiyonundan sonra, $\mathrm{K}$ grubuna göre hem STZ hem de STZ+ABY gruplarında, postprandial kan glukoz düzeyinin anlamlı derecede arttığ1 $(p<0.001)$, deney sonunda ise STZ grubuna göre $\mathrm{STZ}+\mathrm{ABY}$ grubunda postprandial kan glukoz düzeyinin anlamlı derecede azaldığ belirlendi $(p<0.001)$ (Tablo 1).

TABLO 1. Acı badem yağının postprandial kan glukoz düzeyine etkisi (mg/dL)

\begin{tabular}{|c|c|c|c|}
\hline & $\mathbf{K}$ & STZ & $S T Z+A B Y$ \\
\hline Deneyin başlangıcı & $99.83 \pm 0.83$ & $98.00 \pm 1.07$ & $93.33 \pm 0.93$ \\
\hline STZ'den sonra & $92.17 \pm 0.40$ & $296.92 \pm 1.50$ *** & $329.25 \pm 4.51^{\star \star \star}$ \\
\hline Deneyin sonu & $107.33 \pm 1.17$ & $435.91 \pm 9.44^{\star \star *}$ & $343.83 \pm 7.76^{\star \star \star},+++$ \\
\hline
\end{tabular}

TABLO 2. Deneysel Tip 1 diyabet oluşturulmuş sıçanların serum ve eritrositlerinde MDA, GSH ve total protein düzeyindeki değişim.

\begin{tabular}{|c|c|c|c|}
\hline & $\mathbf{K}$ & STZ & STZ+ABY \\
\hline \multicolumn{4}{|l|}{ MDA } \\
\hline Serum (nmol/g) & $5.87 \pm 0.06$ & $8.08 \pm 0.05^{\star \star \star}$ & $6.16 \pm 0.15^{+++,^{\star \star \star}}$ \\
\hline Eritrosit (nmol/g pellet) & $411.32 \pm 2.56$ & $756.35 \pm 8.30^{\star * \star}$ & $358.41 \pm 16.04^{+++,{ }^{* *}}$ \\
\hline \multicolumn{4}{|l|}{ GSH } \\
\hline Eritrosit $\mu \mathrm{mol} / \mathrm{g}$ pellet & $6.15 \pm 0.04$ & $2.09 \pm 0.07^{\star \star \star}$ & $4.44 \pm 0.13^{+++, * \star \star}$ \\
\hline \multicolumn{4}{|l|}{ Total Protein $(\mu \mathrm{g} / \mathrm{g})$} \\
\hline Serum & $42.54 \pm 0.65$ & $41.83 \pm 0.64$ & $48.10 \pm 0.75^{+++, * * *}$ \\
\hline Eritrosit ( $\mu \mathrm{g} / \mathrm{g}$ pellet) & $39.07 \pm 1.83$ & $42.35 \pm 0.79$ & $38.08 \pm 2.75$ \\
\hline
\end{tabular}

Deneysel tip-1 diyabet oluşturulmuş sıçanlarda MDA, GSH ve total protein düzeyindeki değişim Tablo 2' de gösterildi. Kontrol grubuna göre, STZ grubunun hem serum hem de eritrositlerinde MDA düzeyinin anlamlı bir şekilde arttı̆̆ $1(p<0.001)$, eritrositlerde ise GSH düzeyinin anlamlı bir şekilde azaldığ $1(p<0.001)$, serum ve eritrositlerde total protein düzeyinde görülen değişikliklerin istatistiksel açıdan anlamlı olmadığı tespit edildi. STZ grubu ile karşılaştırıldığında, STZ+ABY grubunun serum ve eritrositlerinde MDA düzeyinin anlamlı bir şekilde azaldığ 1 $(p<0.001)$, GSH düzeyinin ise anlamlı bir şekilde $\operatorname{arttığ} 1(p<0.001)$, total protein düzeyinin serumda anlamlı bir şekilde arttığ1 $(p<0.001)$, eritrositlerde ise istatistiksel bir farklılığın olmadığı belirlendi. Kontrol grubu ile karşılaştırıldığında, STZ+ABY grubunun serumunda MDA düzeyinin anlamlı bir şekilde yüksek olduğu $(p<0.001)$, eritrositlerde MDA $(p<0.01)$ ve GSH $(p<0.001)$ düzeylerinin anlamlı bir şekilde azaldığı, total protein düzeyinin serumda anlamlı bir şekilde arttığı $(p<0.001)$ eritrositlerde ise istatistiksel bir farklılığın olmadığı belirlendi.

Deneysel Tip 1 diyabet oluşturulmuş sıçanların serumunda yağ asidi değişimi Tablo 3'de gösterildi. Kontrol grubu ile karşılaştırıldığında, STZ grubunun serumunda 18:1 $(p<0.001)$ ve 18:2 $(p<0.01)$ düzeylerinde kayda değer bir artış, 16:1, 18:0, 20:4 $(p<0.001)$ ve 22:6 $(p<0.05)$ düzeylerinde ise kayda değer bir azalmanın olduğu belirlendi. 16:0 düzeyinde ortaya çıan farklılığın istatistiksel olarak anlamlı olmadığı saptandı. Aynı şekilde STZ grubu ile mukayese edildiğinde, STZ+ABY grubunun serumunda 16:0 ve 18:0 düzeylerinin anlamlı bir şekilde $(p<0.001)$ azaldığı, 18:1 düzeyinin ise anlamlı bir şekilde $(p<0.001)$ arttığı saptandı. 16:1, 18:2, 20:4 ve 22:6 düzeylerinde ortaya çıan değişikliklerin istatistiksel olarak önemli olmadığı belirlendi. Kontrol grubuna göre, STZ+ABY grubunda 16:0 ( $p<0.05), 16: 1,18: 0,20: 4$ ve 22:6 $(p<0.001)$ düzeylerinin anlamlı bir şekilde azaldığı, 18:1 ve 18:2 düzeylerinin ise anlamlı bir şekilde arttığı $(p<0.001)$ saptandı.

TABLO 3. Deneysel Tip 1 diyabet oluşturulmuş sıçanların serumunda yağ asidi değişimi (\%)

\begin{tabular}{|c|c|c|c|}
\hline & $\mathbf{K}$ & STZ & STZ+ABY \\
\hline Palmitik asit $16: 0$ & $21.81 \pm 0.25$ & $22.24 \pm 0.32$ & $20.62 \pm 0.29+++, *$ \\
\hline Palmitoleik asit $16: 1$ & $2.76 \pm 0.08$ & $2.14 \pm 0.04^{* \star *}$ & $2.23 \pm 0.06^{\star \star \star}$ \\
\hline Stearik asit 18:0 & $15.14 \pm 0.50$ & $13.27 \pm 0.32^{\star \star *}$ & $10.57 \pm 0.38^{+++}$ \\
\hline Oleik asit 18:1 & $8.16 \pm 0.40$ & $10.27 \pm 0.31^{\star * *}$ & $14.23 \pm 0.39+++$, \\
\hline Linoleik asit 18:2 & $26.66 \pm 0.46$ & $29.57 \pm 0.76^{* *}$ & $28.88 \pm 0.32^{* * *}$ \\
\hline Araşidonik asit 20:4 & $19.24 \pm 0.34$ & $16.26 \pm 0.21^{\star \star *}$ & $16.60 \pm 0.35^{* * *}$ \\
\hline Dokosaheksaenoik asit 22:6 & $2.57 \pm 0.17$ & $2.16 \pm 0.04^{\star}$ & $2.25 \pm 0.05^{\star \star \star}$ \\
\hline
\end{tabular}


Deneysel Tip 1 diyabet oluşturulmuş sıçanların eritrositlerindeki yağ asidi değişimi Tablo 4 'de gösterildi. Kontrol grubuna göre, STZ grubunda 16:0, 16:1 ve 18:0 düzeylerinin anlamlı bir şekilde $(p<0.001)$ arttığı, 20:4 ve 22:6 düzeylerinin ise anlaml bir şekilde $(p<0.001)$ azaldığı bulundu. 18:1 düzeyinin arttı̆̆1 fakat bu artışın istatistiksel açıdan anlamsız olduğu tespit edildi. 18:2 düzeyinde incelenen guruplar arasında önemli bir farklılığın olmadığı saptandı. STZ grubu ile mukayese edildiğinde, STZ+ABY grubunda 16:0 ( $p<0.001), 16: 1(p<0.001), 18: 0$ $(p<0.05)$ ve 18:1 $(p<0.01)$ düzeylerinin anlamlı bir şekilde azaldığı, 20:4 düzeyinin ise anlamlı bir şekilde $(p<0.001)$ arttığ1, 22:6 düzeylerinde oluşan değişikliğin istatistiksel olarak önemli olmadığı belirlendi. Kontrol grubu ile karşılaştırıld1ğında, STZ+ABY grubunda 16:1 $(p<0.05)$ ve 18:0 $(p<0.01)$ düzeylerinde anlamlı artış, 20:4 $(p<0.01)$ ve 22:6 $(p<0.05)$ düzeylerinde anlamlı azalış, 16:0, 18:1 ve 18:2 düzeylerinde görülen değişikliklerin istatistiksel olarak anlamsız olduğu belirlendi.

TABLO 4. Deneysel Tip 1 diyabet oluşturulmuş sıçanların eritrositlerindeki yağ asidi değişimi (\%)

\begin{tabular}{|c|c|c|c|}
\hline & $\mathbf{K}$ & STZ & $S T Z+A B Y$ \\
\hline Palmitik asit 16:0 & $24.42 \pm 0.25$ & $27.53 \pm 0.27^{\star \star \star}$ & $24.35 \pm 0.30^{+++}$ \\
\hline Palmitoleik asit 16:1 & $2.24 \pm 0.07$ & $2.92 \pm 0.04^{\star \star \star}$ & $2.46 \pm 0.04^{+++, *}$ \\
\hline Stearik asit 18:0 & $12.62 \pm 0.19$ & $14.13 \pm 0.17^{\star \star \star}$ & $13.56 \pm 0.17^{+,{ }^{* *}}$ \\
\hline Oleik asit 18:1 & $7.40 \pm 0.14$ & $7.88 \pm 0.22$ & $6.95 \pm 0.26^{++}$ \\
\hline Linoleik asit 18:2 & $10.91 \pm 0.46$ & $10.27 \pm 0.26$ & $11.08 \pm 0.20$ \\
\hline Araşidonik asit 20:4 & $24.94 \pm 0.22$ & $19.56 \pm 0.35^{\star \star \star}$ & $22.50 \pm .73^{+++,{ }^{* *}}$ \\
\hline $\begin{array}{l}\text { Dokosaheksaenoik } \\
\text { asit } 22: 6\end{array}$ & $1.66 \pm 0.03$ & $1.38 \pm 0.06^{\star \star \star}$ & $1.44 \pm 0.05^{*}$ \\
\hline
\end{tabular}

TABLO 5. Deneysel Tip 1 diyabet oluşturulmuş sıçanların serumunda $E$ ve $K$ vitaminleri, kolesterol ve sterol değişimi $(\mu \mathrm{g} / \mathrm{g})$

\begin{tabular}{|c|c|c|c|}
\hline & $\mathrm{K}$ & STZ & STZ+ABY \\
\hline Vitamin $\mathrm{K}_{2}$ & $0.38 \pm 0.09$ & $0.53 \pm 0.01^{*}$ & $0.42 \pm 0.04$ \\
\hline$\alpha$-Tokoferol & $8.89 \pm 0.26$ & $7.83 \pm 0.19$ & $20,20 \pm 1.09^{+++,{ }^{* \star \star}}$ \\
\hline$\alpha$-Tokoferol asetat & $0.66 \pm 0.02$ & $1.64 \pm 0.02^{\star \star \star}$ & $1.18 \pm 0.04^{+++,{ }^{* \star *}}$ \\
\hline Vitamin $\mathrm{K}_{1}$ & $0.29 \pm 0.04$ & $0.11 \pm 0.02^{\star *}$ & $0.15 \pm 0.04^{*}$ \\
\hline Kolesterol $\mu \mathrm{mol} / \mathrm{g}$ & $1.01 \pm 0.02$ & $0.68 \pm 0.03^{\star \star \star}$ & $0.50 \pm 0.02^{+++, * \star *}$ \\
\hline Stigmasterol & $9.65 \pm 0.40$ & $6.97 \pm 0.23^{\star \star \star}$ & $5.17 \pm 0.20^{+++},{ }^{\star \star \star}$ \\
\hline$\beta$-sitosterol & $6.21 \pm 0.35$ & $3.08 \pm 0.17^{\star \star \star}$ & $4.07 \pm 0.51^{+,{ }^{* \star *}}$ \\
\hline
\end{tabular}

Tablo 5'de deneysel Tip 1 diyabet oluşturulmuş sıçanların serumunda E ve K vitaminleri, kolesterol ve sterol değişimi gösterildi. Kontrol grubu ile karşılaştırıldı̆̆ında, STZ grubunda $\mathrm{K}_{2}(p<0.05)$, ve a-tokoferol asetat düzeylerinin anlamlı bir şekilde $(p<0.001)$ arttığı, $K_{1}(p<0.01)$, kolesterol, stigmasterol ve $\beta$-sitosterol düzeylerinin ise anlamlı bir şekilde $(p<0.001)$ azaldığı, a-tokoferol düzeyinde ortaya çıkan değişikliğin istatistiksel açıdan önemli olmadığı belirlendi. Aynı şekilde STZ grubu ile mukayese edildiğinde, STZ+ABY grubunun serumunda a-tokoferol $(p<0.001)$ ve $\beta$-sitosterol $(p<0.05)$ düzeylerinin anlamlı bir şekilde arttığı, a-tokoferol asetat, kolesterol ve stigmasterol düzeylerinin ise anlamlı bir şekilde $(p<0.001)$ azaldığı saptandı. $K_{2}$ ve $K_{1}$ düzeyinde ortaya çıkan değişikliklerin istatistiksel olarak önemli olmadığı bulundu. Kontrol grubuna göre, STZ+ABY grubunda a-tokoferol ve a-tokoferol asetat düzeylerinin anlamlı bir şekilde $(p<0.001)$ arttı̆̆ı, vitamin $K_{1}$ $(p<0.05)$, kolesterol, stigmasterol ve $\beta$-sitosterol düzeylerinin anlamlı bir şekilde $(p<0.001)$ azaldığıı, vitamin $K_{2}$ düzeyinde ortaya çıkan değişikliğin istatistiksel olarak anlamlı olmadığı tespit edildi.

Tablo 6' da deneysel Tip 1 diyabet oluşturulmuş sıçanların eritrositlerinde a-tokoferol, K vitamini, kolesterol ve sterol değişimi gösterildi. Kontrol grubuna göre, STZ grubunda $K_{2}$ ve a-tokoferol düzeylerinin anlamlı bir şekilde $(p<0.001)$ azaldığı, a-tokoferol asetat ve kolesterol düzeylerinin ise anlamlı bir şekilde $(p<0.001)$ arttığ belirlendi. $K_{1}$, stigmasterol ve $\beta$-sitosterol düzeylerinde ortaya çıkan değişikliklerin ise istatistiksel aç1dan önemsiz olduğu tespit edildi. Yine STZ grubu ile karşılaştırıldığında, STZ+ABY grubunun eritrositlerinde a-tokoferol, a-tokoferol asetat, $\mathrm{K}_{1}$, stigmasterol ve $\beta$-sitosterol düzeylerinin anlamlı bir şekilde $(p<0.001)$ arttığı, $K_{2}$ ve kolesterol düzeylerinde ortaya çıkan değişikliklerin istatistiksel olarak önemli olmadığı belirlendi. Kontrol grubu ile mukayese edildiğinde, STZ+ABY grubunun eritrositlerinde vitamin $K_{2}$ düzeyinin anlamlı bir şekilde $(p<0.001)$ azaldığı, a-tokoferol asetat, vitamin $K_{1}$, kolesterol, stigmasterol ve $\beta$-sitosterol düzeylerinin anlamlı bir şekilde $(p<0.001)$ arttığ1, a-tokoferol düzeyinde ortaya çıkan değişikliğin istatistiksel olarak önemli olmadığı saptand1.

TABLO 6. Deneysel Tip 1 diyabet oluşturulmuş sıçanların eritrositlerinde $E$ ve K vitaminleri, kolesterol ve sterol değişimi $(\mu \mathrm{g} / \mathrm{g})$

\begin{tabular}{|c|c|c|c|}
\hline & $\mathbf{K}$ & STZ & STZ+ABY \\
\hline Vitamin $\mathrm{K}_{2}$ & $1.69 \pm 0.14$ & $0.48 \pm 0.02^{* * *}$ & $0.48 \pm 0.01^{* \star *}$ \\
\hline$\alpha$-Tokoferol & $6.40 \pm 0.22$ & $3.03 \pm 0.11 \mathrm{~d}^{\mathrm{d} * \star}$ & $6.11 \pm 0.24^{+++}$ \\
\hline$\alpha$-Tokoferol asetat & $2.15 \pm 0.06$ & $3.68 \pm 0.11^{\star \star \star}$ & $5.86 \pm 0.12^{+++, * \star \star}$ \\
\hline Vitamin $\mathrm{K}_{1}$ & $0.36 \pm 0.02$ & $0.40 \pm 0.03$ & $1.10 \pm 0.12^{+++,{ }^{* * *}}$ \\
\hline Kolesterol $\mu \mathrm{mol} / \mathrm{g}$ & $1.77 \pm 0.03$ & $2.46 \pm 0.12^{\star \star \star}$ & $2.28 \pm 0.06^{\star \star *}$ \\
\hline Stigmasterol & $16.61 \pm 0.50$ & $16.51 \pm 0.35$ & $22.32 \pm 0.65^{+++,{ }^{* * \star}}$ \\
\hline$\beta$-sitosterol & $10.83 \pm 0.38$ & $10.71 \pm 0.13$ & $16.69 \pm 0.46^{+++,^{* \star \star}}$ \\
\hline
\end{tabular}

\section{TARTIŞMA}

Diyabette postprandial kan glukoz düzeyinin açlık kan glukoz düzeyine göre daha iyi bir belirteç olduğu ifade edilmiştir (22). Diyabette hem açlık kan glukoz hem de postprandial kan glukoz düzeyinin azaltılması glisemik kontrol sağlamanın yanında diyabete özgü komplikasyonlarının önlenmesi açısından da oldukça önemlidir (23). Yaptığımız çalışmada, STZ grubunda postprandial kan glukoz düzeyinin arttığı, acı badem yağı uygulana grupta ise postprandial kan glukoz düzeyinin azaldığ1 saptandı (Tablo 1). Yapılan çalışmalarda bademde kateşin, epikateşin, siyanidin ve prosiyanidin $(24,25)$ gibi fenolik bileşiklerin bulunduğu ve bu bileşiklerinden: prosiyanidinlerin alfa glukozidaz aktivitesini engellediği (26), epikateşinin pankreasta bulunan beta hücre rejenerasyonuna neden olduğu (27), kateşin ve siyanidinlerin bağırsakta glikoz emilimini inhibe ettiği rapor edilmiştir $(28,29,30)$. Yukarıda bahsedilen fenolik bileşiklerin metabolik reaksiyonlar üzerindeki aktivitesinden dolayı acı badem yağı uyguladığımız grupta kan glukoz düzeyinin azaldığı$\mathrm{n} 1$ düşünmekteyiz. Yapılan bir çalışmada, acı badem çekirdeğinden elde edilen ekstraktın diyabetik farelere uygulanması 
neticesinde doza bağlı olarak kan glukoz düzeyini kontrol grubu değerlerine yaklaştırdığı belirlendi (31).

Pankreas adacıklarında bulunan $\beta$-hücreleri kan-glikoz homeostazını etkili bir şekilde regüle etmektedir. Bu aktivitenin sürdürülmesi, hem $\beta$-hücrelerinin yoğunluğuna hem de bu hücrelerin salgıladığı insülin miktarına bağlıdır. Pankreasta bulunan $\beta$-hücreleri diyabetin etiyolojisinde çok önemli rol oynamaktadır (32). Deney hayvanlarına STZ verilmesine müteakip kanda insülin düzeyi azalmakta, glukoz düzeyi ise artmaktadır (33). Diyabette kan glikoz düzeyinin sürekli yüksek olması reaktif oksijen türlerinin (ROS) üretiminde artışa yol açmakta, buda glikozun otooksidasyonu ile protein glikozilasyonuna sebep olmaktadır. Serbest radikaller normal hücre metabolizması esnasında yan ürün olarak oluşmakta, ancak bazı koşullarda hücresel savunma sistemleri ile ROS üretimi arasında mevcut olan denge bozulmaktadır (34). Bu dengesiz durum hücre disfonksiyonu ile hücre ölümün yol açarak sonuçta doku hasarına sebep olabilmektedir. Birçok dejeneratif hastalıkta lipit peroksidasyon (LPO) düzeyinin arttığı ifade edilmekle birlikte, hem doğal hem de kimyasal maddeler (streptozotosin, alloksan) kullanılarak yapılan diyabette LPO düzeyinin arttı̆̆ı pek çok çalışmada ortaya çıkmıştır (35). Diyabette LPO düzeyinin artığ1, antioksidan savunma aktivitesinin azaldığ ${ }_{1}$ bu durumunda diyabete özgü komplikasyonların gelişimini hızlandırdığı, bu komplikasyonlarında hasta yaşam kalitesini ciddi anlamda etkilediği birçok araştırmacı tarafından kabul edilen bir gerçektir (36, 37).

Yaptığımız çalışmada diyabetik sıçanların serum ve lipit peroksidasyonunun en önemli göstergelerinden olan MDA düzeyinin anlamlı bir şekilde arttığı, uyguladığımız acı badem yağı sonucunda hem serum hem de eritrositlerde MDA düzeyinin anlamlı bir şekilde azaldığı belirlendi (Tablo 2). Şekeroğlu ve arkadaşları, yaptıkları çalışmada diyabetik kişilerin serum ve eritrositlerinde MDA düzeyinin arttığını rapor etmişler (38). Murugan ve Pari, yaptıkları çalışmada diyabetik sıçanların eritrosit membranında MDA düzeyinin arttığını, antioksidan enzimlerin aktivitesinin azaldığını, uyguladıkları tedavi edici ajanın oluşan bu değişiklikleri önlediğini belirtmişler (39). Karbon tetraklorür $\left(\mathrm{CCl}_{4}\right)$ verilerek karaciğer hasarı oluşturulan sıçanlarda MDA düzeyinin arttığı, bu sıçanlara uygulanan badem yağının doza bağlı olarak MDA düzeyini azalttığı bildirilmiştir (10). Aynı şekilde sarımsak yağının da doza bağlı olarak MDA düzeyini azalttığı bildirilmiştir (13). Acı badem çekirdeklerinin hipoglisemik aktiviteye sahip olduğu bildirilmektedir (40). Ayrıca, acı badem çekirdeği, çiçeği ve yaprağından elde edilen ekstraktların ayrı ayrı diyabetik farelere uygulanması sonucunda serum biyokimyasal parametreleri üzerinde diyabetin neden olduğu metabolik anormalliklerin düzeldiği rapor edilmiştir (31). MDA düzeyi için elde ettiğimiz bulguların yukarıda bahsedilen çalışma bulguları ile uyum içinde olduğunu tespit ettik. Acı badem yağı uyguladığımız grupta MDA düzeyinde ortaya çıkan azalmanın acı badem yağında bulunan antioksidan bileşiklerin varlığından dolayı ortaya çıktığını düşünmekteyiz. Acı bademin antioksidan potansiyelinin olduğu çalışmalarda ortaya çıkmıştır (12).

Glutatyon, serbest radikal temizleme ve serbest radikallerin neden olduğu biyolojik hasarı onarma kabiliyeti bulunan önemli bir antioksidan moleküldür. GSH, detoksifikasyon reaksiyonlarına katılarak serbest radikalleri etkisizleştirmekte, redoks homeostazını koruma yolu ile de normal hücre yapı ve fonksiyonunun sürdürülmesini desteklemektedir. Elde ettiğimiz bulgularda, diyabet grubunda GSH düzeyinin azaldığ1, acı badem yağı uygulanan grupta ise GSH düzeyinin arttığ tespit edildi (Tablo 2). Diyabette GSH düzeyinin azalması, oksidatif strese karşı vücut tarafından kullanımının arttığını göstermektedir (41). $\mathrm{CCl}_{4}$ verilerek karaciğer hasarı oluşturulan sıçanlarda antioksidan enzimlerin aktivitelerinin azaldığı, doza bağlı olarak uygulanan badem yağı sonucunda bu enzimlerin aktivitelerinin arttığı saptandı (10). Diyabetik sıçanlarda, aktiviteleri azalan antioksidan (superoksit dismutaz, katalaz, glutatyon peroksidaz gibi), uygulanan susam yağı ile aktivitelerini geri kazandıkları ifade edilmiştir (42). Yapılan benzer çalışmalarda da diyabetik sıçanların çeşitli dokularında GSH düzeyinin azaldığı, uygulanan fitokimyasallar ile çeşitli bitki ekstraktlarının GSH düzeyinde artışa yol açtığı saptanmıştır $(43,44,45)$. Diyabetik sıçanlara uyguladığımız acı badem yağında bulunan çeşitli antioksidan bileşiklerin oksidatif strese karşı vücudun antioksidan savunma sistemini desteklemiş olduğundan dolayı eritrositlerde GSH düzeyinin arttığını düşünmekteyiz (Tablo 2).

Yağ asitleri eikosanoid öncülü ve aynı zamanda vücuttaki her hücrenin yapı ve fonksiyonu için gerekli olan moleküllerdir. Hem doğal hem de deneysel diyabette serum ve çeşitli dokularda yağ asidi kompozisyonunun değiştiği bilinmektedir $(46,47)$.

Palmitik ve stearik asit organizmada en çok bulunan doymuş yağ asitlerindendir. Yaptığımız çalışmada STZ grubunun eritrositlerinde palmitik ve stearik asit düzeyinin arttığı, serumda stearik asit düzeyinin azaldığı, palmitik asit düzeyinin arttığı, acı badem yağı uyguladığımız grubun eritrositlerinde ise palmitik ve stearik asit düzeyinin azaldığını tespit ettik. Bohov ve arkadaşları, yaptıkları çalışmada diyabetik kişilerin serumunda stearik asit düzeyinin azaldığını tespit etmişler (48). Albutt ve Chance, diyabet grubuna göre, diyabetik çocuklara uyguladıkları mısır yağının plazmada palmitik ve stearik asit düzeyini azalttı̆̆ını belirlemişler (49). Murugan ve Pari, diyabetik s1çanların karaciğer, böbrek ve beyin dokusunda palmitik ve stearik asit düzeyinin arttığını, diyabetik sıçanlara uyguladıkları tetrahidrokurkumin ve kurkumininin oluşan bu artışı azaltarak kontrol gurubu değerlerine yaklaştırdığını belirlemişler (50), bu bağlamda elde ettiğimiz bulguların daha önce yapılan çalışma bulgularıyla uyum içinde olduğunu saptadık.

Metabolizmada palmitoleik ve oleik asit en yaygin olarak bulunan tekli doymamış yağ asitlerindendir. Oleik asit (18:1), badem yağında bol miktarda bulunmaktadır (51). Yapılan çalışmalarda tekli doymamış yağ asitlerinin insülin duyarlılığını arttırdığı, ancak insülin sekresyonuna etki etmediği tespit edilmiştir (52). Bohov ve arkadaşları ve Albutt ve Chance, yaptıkları çalışmada diyabetik bireylerin plazmasında palmitoleik (16:1) asit düzeyinin azaldığını, oleik asit (18:1) düzeyinin arttığını tespit etmişler $(48,49)$. Elde ettiğimiz verilerle, yukarıdaki çalışma verilerinin uyumlu olduğu görülmektedir. Igal ve arkadaşları, diyabet oluşturulmuş sıçanlara verdikleri mısır (badem yağı ile benzer yağ asidi kompozisyonuna sahip) yağı sonucunda kontrol grubuna göre, diyabet grubunun karaciğer mikrozomlarında palmitoleik asit miktarının azaldığını, oleik asit miktarının ise arttığını rapor etmişler (53). Albutt ve Chance, uzun dönem misır yağı verdikleri diyabetli çocukları misır yağı verilmeyen 
diyabetli çocuklarla karşılaştırdıklarında, mısır yağı verdikleri çocukların plazmalarında palmitoleik asit miktarının azaldığ1nı, oleik asit miktarının azalarak kontrol grubu değerlerine yaklaştığını tespit etmişler (49). Acı badem yağı uyguladığımız diyabetik sıçanların serumunda palmitoleik asit miktarının kontrol grubu değerlerine yaklaştığı, oleik asidin daha da arttığı, eritrositlerde ise palmitoleik ve oleik asit miktarının azalarak kontrol grubu değerine yaklaştığını belirledik (Tablo 3,4). 16:1 ve 18:1 gibi tekli doymamış yağ asitlerinin sentezini steroil CoA desaturaz (delta-9 desaturaz) katalizlemektedir. Bu enzimin aktivitesi diyet ve diyabete bağlı olarak değişmekte $(55,56,57)$, özellikle serumda yağ asidi düzeyinde oluşan değişikliklerin delta-9 desaturaz aktivitesinde ortaya çıkan azalmadan dolayı ortaya çıktığını öngörmekteyiz.

Linoleik, araşidonik ve dokosaheksaenoik asit delta-6 ile delta-5 desaturaz aktivitesi neticesinde oluşan yağ asitleridir. Bu enzimlerin aktivitesine insülin ve diyet etki etmektedir $(58,59)$. Yaptığımız çalışmada diyabetik sıçanların serumunda linoleik asit düzeyinin arttığı, aaraşidonik ve dokosaheksaenoik asit düzeyinin azaldığı, acı badem yağı uygulanması neticesinde linoleik asit düzeyinin azaldığı, araşidonik ve dokosaheksaenoik asit düzeyinin ise artarak kontrol grubu değerlerine yaklaştığı tespit edildi (Tablo 3,4). STZ grubunda ortaya çıkan anormalliklerin metabolizmada insülin düzeyinde ortaya çıkan azalmadan kaynaklandığını düşünmekteyiz çünkü STZ kullanılarak diyabet oluşturulmuş sıçanlarda insülin eksikliğinin olduğu ifade edilmiştir (33). Acı badem yağı uygulanan sıçanlarda ise acı bademin delta-6 ile delta-5 desaturaz enzim aktivitesini etkilemesi neticesinde linoleik, araşidonik ve dokosaheksaenoik asit düzeyinde olumlu etkilerin ortaya çıktığını öngörmekteyiz. Yağ asidi sentezine katılan enzimlerin aktivitesinin diyete bağlı olarak değişebildiği ifade edilmiştir $(60,61)$.

a-tokoferol (E vitamini) zincir kırıcı özelliği olan bir antioksidan moleküldür. STZ kullanılarak diyabet oluşturulan sıçanlarda a-tokoferolün biyokimyasal ve metabolik parametreler üzerinde olumlu etkiler gösterdiği çalışmalarla ortaya konulmuştur (62). Elde ettiğimiz bulgulara göre, diyabetik sıçanlarda a-tokoferol düzeyinin azaldığı, diyabetik sıçanlara uygulanan acı badem yağı neticesinde a-tokoferol düzeyinin serum ve eritrositte arttığını belirledik. Elde ettiğimiz bulgulara göre, diyabetin neden olduğu olumsuz koşullarda, a-tokoferolün koruyucu özellik gösterdiği söylenebilir. Zaten yapılan çalışmalarda da E vitamininin diyabete özgü komplikasyonların ortaya çıkmasını geciktirdiği gibi komplikasyonların ilerlemesini yavaşlattığı ileri sürülmüştür (63). Ortaya çıkan bu etkinin a-tokoferolün antioksidan özelliğinden ileri geldiği ifade edilmiştir (64). Aynı zamanda badem yağının iyi bir a-tokoferol kaynağı olduğu bilinmektedir (51).
Kolesterol, hücre membran yapısı ile fonksiyonunun sürdürülmesinde önemli rolü olan moleküldür (65). Elde ettiğimiz bulgulara göre, STZ grubunun serumunda total kolesterol düzeyinin azaldığı, acı badem yağı verilen grupta daha da azaldığı, eritrositlerde ise diyabet gruplarında (STZ, STZ+ABY) kolesterol düzeyinin arttığı tespit edildi. Noyan ve arkadaşları, STZ vererek diyabet yaptıkları sıçanların serumunda kolesterol düzeyinin kontrol gurubuna göre azaldığını tespit etmişler (66). Diyabette eritrosit membranında kolesterol düzeyinin arttığ1 yapılan çalışmalarda ortaya çıkmıştır $(67,68)$. Uyguladığımız acı badem yağı neticesinde eritrositlerde kolesterol düzeyinin önemsiz bir şekilde azaldığı saptand1. 3-Hidroksi-3-metilglutaril CoA redüktaz kolesterol biyosentezinin hız sınırlayıcı basamağını oluşturmakta ve diyabetik sıçanlarda aktivitesinin artığ belirlenmiştir. Yine diyabette, kolesterol aciltransferaz ve fenol 2-monooksijenaz aktivitesinin değiştiği ifade edilmiştir (69). Diyabetik sıçanların eritrositlerinde, kolesterol düzeyinde ortaya çıkan değişikliklerin kolesterol biyosentezine katılan enzimlerin aktivitelerinin diyabet koşullarından etkilenmesinden dolayı ortaya çıktığını düşünmekteyiz. Diyabetik sıçanların serum kolesterol düzeyinde ortaya çıan azalmanın, bademde bol miktarda bulunan monounsature yağ asitlerinin varlığından dolayı ortaya çıkmış olabilir. Lovejoy ve arkadaşları, diyabetli kişilerde bademin kan yağları üzerinde yararlı etkiler gösterdiğini tespit etmişlerdir (70).

Diyabetik sıçanların serum ve eritrositlerinde $\beta$-sitosterol ile stigmasterol düzeylerinde önemli değişikliklerin olduğu, uygulanan acı badem yağı sonucunda $\beta$-sitosterol düzeyinin arttığ1 stigmasterol düzeyinin ise azaldığı, eritrositlerde ise $\beta$-sitosterol ile stigmasterol düzeylerinin arttığı belirlendi. Badem fitosterol açısından zengin bir besindir (51). Alhazzaa ve arkadaşları, s1çanlara 1000 (düşük doz) ile 4000 (yüksek doz) mg/kg fitosterol verdikleri grubu, fitosterol verilmeyen grup ile karşılaştırdıklarında yüksek doz fitosterol verilen grupların eritrositlerde fitosterol düzeyinin iki katına çıktığını ifade etmişler (71). Bu çalışmada bize fitosterol bakımından zengin beslenmenin dokularda fitosterol birikimine yol açacağını göstermektedir. Elde ettiğimiz verilerde de, eritrositlerde sterol düzeyinde artış olduğu, bu açıdan bakıldığında elde ettiğimiz verilerin yukarıdaki çalışma verileriyle uyum gösterdiği görülmektedir.

Sonuç olarak elde ettiğimiz verilere göre diyabetik sıçanlara uyguladığımız acı badem yağının lipid peroksidasyon ve glutatyon düzeyi üzerindeki faydalı etkilerine ek olarak yağ asidi kompozisyonu ile a-tokoferol düzeyi üzerindeki olumlu etkilerinden dolayı, acı badem gibi kuru yemişlerin diyabet hastaları tarafından kullanılmasının, iyi bir diyet stratejisi göstermekte, fakat bu çalışma verilerinin kapsamlı çalışma verileriyle desteklenmesi gerekmektedir. 
The effects of bitter almond oil on some biochemical parameters in serum and erythrocytes of streptozotocin-induced Type-1 diabetic rats

ABSTRACT: The present study was designed to evaluate the efficacy of bitter almond oil on some biochemical parameters in serum and erythrocytes of streptozotocin-induced type-1diabetic rats. The rats were divided into three groups: Control (C); Diabetes (STZ); Diabetes+Bitter almond oil (STZ+BAO). Experimental diabetes induced in rats with a single intraperitoneal streptozotocin injection $(65 \mathrm{mg} / \mathrm{kg}) .1 \mathrm{ml} / \mathrm{kg}$ dose of bitter almond oil was intraperitoneally injected to bitter almond oil group rats (STZ+BAO) twice in a week and additionally $2 \mathrm{~g} / 500 \mathrm{ml}$ dose of bitter almond seed powder was added to the drinking water of these rats. According to control group, postprandial blood glucose level was significantly increased $(p<0.001)$ in the STZ group; but its level was significantly decreased $(p<0.001)$ in the STZ+BAO group when compared to the STZ group. Malondialdehyde (MDA) levels of serum and erythrocytes increased significantly $(p<0.001)$ in STZ group and glutathione $(G S H)$ level erythrocytes decreased significantly $(p<0.001)$ when compared to control group. It was detected that, MDA levels of serum and erythrocytes significantly decreased $(p<0.001)$ in the STZ+BAO group and GSH levels were significantly $(p<0.001)$ inreased compared to STZ group. In the serum, the palmitic and linoleic acid levels; in the erythrocytes, the palmitic, palmitoleic, stearic, arachidonic and docosahexaenoic acid levels were closed to the control group values in the STZ+BAO group. In also, in the serum, $\alpha$-tocopherol acetate and $\beta$-sitosterol levels; in the erythrocytes, $\alpha$-tocopherol levels were closed to the control group values in the same group. The $\alpha$-tocopherol level was increased in the serum of STZ+BAO group when comparison to the STZ group. In conclusion, it was determined that the treatment of bitter almond oil positively affected lipid peroxidation, glutathione, fatty acids and $\alpha$-tocopherol levels in the serum and erythrocytes of diabetic rats. According to our study results, bitter almond oil consumption could be a good diet strategy in the treatment of diabetes, but these results should be supported by detail researchs.

KEY WORDS: Diabetes, streptozotocin, bitter almond oil, lipid peroxidation, $\alpha$-tocopherol, fatty acid composition

\section{KAYNAKLAR}

1. Jakus V. The role of free radicals, oxidative stress and antioxidant systems in diabetic vascular disease. Bratislava Med 2000; 101(10): 541-551.

2. Giacco F, Brownlee M. Oxidative stress and diabetic complications. Cir Res 2010; 107: 1058-70.

3. Karatug A, Bolkent S. The potential role of combined antioxidant treatment on pancreas of STZ-diabetic mice. Exp Toxicol Pathol 2013; 65: 255-62.

4. Prabakaran D, Ashokkumar N. Protective effect of esculetin on hyperglycemia-mediated oxidative damage in the hepatic and renal tissues of experimental diabetic rats. Biochimie 2013; 95:366-73.

5. El-Moselhy MA, Taye A, Sharkawi SS, El-Sisi SF, Ahmed AF. The antihyperglycemic effect of curcumin in high fat diet fed rats. Role of TNF-a and free fatty acids. Food Chem Toxicol 2011; 49:1129-40.

6. Prabhakar PK, Prasad R, Ali S, Doble M. Synergistic interaction of ferulic acid with commercial hypoglycemic drugs in streptozotocin induced diabetic rats. Phytomedicine 2013; 20:488-94.

7. Ahmad Z. The uses and properties of almond oil. Complemen Ther Clin Pract 2010; 16:10-12.

8. Tuzlacı E, Şenkardeş İ. Turkish folk medicinal plants, $X$ : Ürgüp (Nevşehir). Marmara Pharm J 2011; 15:58-68.

9. Pandeya KB, Tripathi IP, Mishra MK, Dwivedi N, Pardhi Y, Kamal A, Gupta P, Dwivedi N, Mishra C. A critical review on traditional herbal drugs: An emerging alternative drug for diabetes. Int J Org Chem 2013; 3:1-22.

10. Jia $X Y$, Zhang $Q A$, Zhang $Z Q$, Wang $Y$, Yuan JF, Wang HY, Zhao D. Hepatoprotective effects of almond oil against carbon tetrachloride induced liver injury in rats. Food Chem 2011; 125:673-8.
11. Miraliakbari $H$, Shahidi $F$. Antioxidant activity of minor components of tree nut oils. Food Chem 2008; 111:421-7.

12. Esfahlan AJ, Jamei R. Properties of biological activity of ten wild almond (Prunus amygdalus L.) species. Turkish J Biol 2012; 36:201-9.

13. Liu CT, Hsu TW, Chen KM, Tan YP, Lii CK, Sheen LY. The antidiabetic effect of garlic oil is associated with ameliorated oxidative stress but not ameliorated level of pro-inflammatory cytokines in skeletal muscle of streptozotocin-induced diabetic rats. J Traditional Complem Med 2012; 2:135-44.

14. Movahedian A, Zolfaghari B, Sajjadi SE, Moknatjou R. Antihyperlipidemic effect of Peucedanum pastinacifolium extract in streptozotocin-induced diabetic rats. Clinics 2010; 65:629-33.

15. Lowry OH, Rosebrough NJ, Farr AL, Randall RJ. Protein measurement with the Folin phenol reagent. J Biol Chem 1951; 193: 265-75.

16. Ohkawa H, Oshishi N, Yagi K. Assay for lipid peroxides in animal tissues by thiobarbuturic acid reaction. Analytical Biochemistry 1979; 95: 351-8.

17. Ellman GL. Tissue sulfhydryl groups. Arch Biochem Biophy 1959; 82: 70-7.

18. Hara A, Radin NS. Lipid extraction of tissues with a lowtoxicity solvent. Anal Biochem 1978; 90: 420-6.

19. Christie WW. Gas Chromatography and Lipids. The Oil Press, Glaskow. 1992.

20. Sánchez-Machado DI, López-Hernández J, PaseiroLosada P, López-Cervantes J. An HPLC method for the quantification of sterols in edible seaweeds. Biomed Chromatog 2004; 18: 183-90. 
21. Katsanidis E, Addis PB. Novel HPLC analysis of tocopherols, tocotrienols, and cholesterol in tissue. Free Radic Biol Med 1999; 27: 1137-1140.

22. Bozkurt M, Kayataş $K$, Uslu İ, Saraçoğlu $S$, Taştan EZ, Erhan N. Tip 2 diabetes mellitusta koroner arter hastalığ1 risk faktörü olarak postprandial kan şekeri. Haseki Tip Bülteni 2005; 43: 1-6.

23. Ejike CE, Awazie SO, Nwangozi PA, Godwin CD. Synergistic postprandial blood glucose modulatory properties of Vernonia amygdalina (Del.), Gongronema latifolium (Benth.) and Occimum gratissimum (Linn.) aqueous decoctions. J Ethnopharmacol 2013; 149: 111-6.

24. Amarowicz R, Troszyńska A, Shahidi F. Antioxidant activity of almond seed extract and its fractions. J Food Lipids 2005; 12: 344-58.

25. Milbury PE, Chen CY, Dolnikowski GG, Blumberg JB. Determination of flavonoids and phenolics and their distribution in almonds. J Agric Food Chem 2006; 54: 5027-33.

26. Schäfer A, Högger P. Oligomeric procyanidins of French maritime pine bark extract (Pycnogenol) effectively inhibit alpha-glucosidase. Diabetes Clin Pract 2007; 77: 41-6.

27. Kim MJ, Ryu GR, Chung JS, Sim SS, Min DS, Rhie DJ, Yoon $\mathrm{SH}$, Hahn SJ, Kim MS, Jo YH. Protective effects of epicatechin against the toxic effects of streptozotocin on rat pancreatic islets: in vivo and in vitro. Pancreas 2003; 26: 292-9.

28. Shimizu M, Kobayashi $Y$, Suzuki M, Satsu H, Miyamoto Y. Miyamoto, Regulation of intestinal glucose transport by tea catechins. Biofactors 2000; 13: 61-5.

29. Adisakwattana $S$, Yibchok-Anun $S$, Charoenlertkul $P$, Wongsasiripat N. Adisakwattana S, Yibchok-Anun S, Charoenlertkul P, Wongsasiripat N. Cyanidin-3rutinoside alleviates postprandial hyperglycemia and its synergism with acarbose by inhibition of intestinal a-glucosidase. J Clin Biochem Nutr 2011; 49: 36-41.

30. Akkarachiyasit $S$, Yibchok-Anun $S$, Wacharasindhu $S$, Adisakwattana S. In vitro inhibitory effects of cyandin3-rutinoside on pancreatic a-amylase and its combined effect with acarbose. Molecules 2011;16: 2075-2083.

31. Shah KH, Patel JB, Shrma VJ, Shrma RM, Patel RP, Chaunhan UM. Evaluation of antidiabetic activity of Prunus amygdalus batsch in streptozotocin induced diabetic mice. Res J Pharm Biol Chem Sci 2011; 2: 429-34.

32. Ramesh B. Dietary management of pancreatic beta-cell homeostasis and control of diabetes. Medical Hypotheses 1996; 46: 357-61.

33. Ugarte M, Brown M, Hollywood KA, Cooper GJ, Bishop PN, Dunn WB. Metabolomic analysis of rat serum in streptozotocin-induced diabetes and after treatment with oral triethylenetetramine (TETA). Genome Med 2012; 4:1-15.

34. Moussa SA. Oxidative stress in diabetes mellitus. Romanian J Biophys 2008; 18: 225-36.

35. MeloSS, Meirelles MS, Jordão Júnior AA, Vannucchi H. Lipid peroxidation in nicotinamide-deficient and nicotinamidesupplemented rats. Acta Diabetol 2000; 37: 33-39.

36. Fowler MJ. Microvascular and macrovascular complications of diabetes. Clin Diabetes 2008; 26:77-82.

37. Ceriello A. New insights on oxidative stress and diabetic complications may lead to a "causal" antioxidant therapy. Diabetes Care 2003; 26:1589-96.
38. Şekeroğlu MR, Şahin $H$, Dülger $H$, Algün E. The effect of dietary treatment on erythrocyte lipid peroxidation, superoxide dismutase, glutathione peroxidase, and serum lipid peroxidation in patients with type 2 diabetes mellitus. Clin Biochem 2000; 33:669-74.

39. Murugan P, Pari L. Influence of tetrahydrocurcumin on erythrocyte membrane bound enzymes and antioxidant status in experimental type 2 diabetic rats. J Ethnopharmacol 2007; 113:479-86.

40. Teotia S, Singh M. Hypoglycemic effect of Prunus amygdalus seeds in albino rabbits. Indian J Exp Biol 1997; 35:295-6.

41. Pari L, Saravanan R. Beneficial effect of succinic acid monoethyl ester on erythrocyte membrane bound enzymes and antioxidant status in streptozotocinnicotinamide induced type 2 diabetes. Chem Biol Interac 2007; 169: 15-24.

42. Ramesh B. Beneficial effect of substitution of sesame oil on hepatic redox status and lipid parameters in streptozotocin diabetic rats. I.J.S.N. 2011; 2:488-93.

43. Ramesh B, Pugalendi KV. Antioxidant role of Umbelliferone in STZ-diabetic rats. Life Sci 2006; 79:306-10.

44. Karthikesan K, Pari L, Menon VP. Protective effect of tetrahydrocurcumin and chlorogenic acid against streptozotocin-nicotinamide generated oxidative stress induced diabetes. J Funct Foods 2010; 2:134-42.

45. Aslan M, Deliorman OD, Orhan N, Sezik E, Yesilada E. In vivo antidiabetic and antioxidant potential of Helichrysum plicatum ssp. plicatum capitulums in streptozotocin-induced-diabetic rats. J Ethnopharmacol 2007; 109: 54-9.

46. Pelikanova T, Kohout M, Valek J, Base J, Stefka Z. Fatty acid composition of serum lipids and erythrocyte membranes in type 2 (non-insulindependent) diabetic men. Metabolism 1991; 40:175-80.

47. Huang YS, Horrobin DF, Manku MS, Mitchell J, Ryan MA. Tissue phospholipid fatty acid composition in the diabetic rat. Lipids 1984; 19:367-70.

48. Bohov $\mathrm{P}$, Gelienová K, Seböková E, Klimes I. Abnormal serum fatty acid composition in non-insulin-dependent diabetes mellitus. Ann NY Acad Sci 1993; 683:367-70.

49. Albutt EC, Chance GW. Plasma and adipose tissue fatty acids of diabetic children on long-term corn oil diets. J Clin Invest 1969; 48:139-45.

50. Murugan P, Pari L. Protective role of tetrahydrocurcumin on changes in the fatty acid composition in streptozotocinnicotinamide induced type 2 diabetic rats. J App Biomed 2007; 5:31-8.

51. Yada S, Lapsley K, Huang G. A review of composition studies of cultivated almonds: Macronutrients and micronutrients. J Food Compos Analysis 2011; 24:469-80.

52. Vessby B, Uusitupa M, Hermansen $K$, Riccardi G, Rivellese AA, Tapsell LC, Nälsén C, Berglund L, Louheranta A, Rasmussen BM, Calvert GD, Maffetone A, Pedersen E, Gustafsson IB, Storlien LH. Substituting dietary saturated for monounsaturated fat impairs insülin sensitivity in healthy men and women: the KANWU study. Diabetologia 2001; 44:312-9.

53. Igal A, de Gómez Dumm NT. Influence of dietary n-3 fatty acids on the biosynthesis of polyunsaturated fatty acids in STZ-diabetic rats. J Nutr Biochem 1995; 6:269-74. 
54. Giacometti J, Tomljanovic AB, Milin C, Cuk M, Stasic BR. Olive and corn oil enriched diets changed the phospholipid fatty acid composition in mice liver after one-thirds hepatectomy. Food Nutr Sci 2012; 3:240-8.

55. Worcester NA, Bruckdorfer KR, Hallinan T, Wilkins AJ, Mann JA, Yudkins J. The influence of diet and diabetes on stearoyl Coenzyme A desaturase (EC 1.14.99.5) activity and fatty acid composition in rat tissues. B J Nutr 1979; 41:239-52.

56. Ntambi JM. Regulation of stearoyl-CoA desaturase by polyunsaturated fatty acids and cholesterol. J Lipid Res 1999; 40:1549-58.

57. Attie AD, Flowers MT, Flowers JB, Groen AK, Kuipers F, Ntambi JM. Stearoyl-CoA desaturase deficiency, hypercholesterolemia, cholestasis, and diabetes. Nutr Rev 2007; 65:35-8.

58. Raz A, Belsky NK, Przedecki F, Obukowicz M. Dietary fish oil inhibits $\Delta 6$-desaturase activity in vivo. J Am Oil Chem Soc 1998; 75:241-5.

59. Rimoldi OJ, Finarelli GS, Brenner RR. Effects of diabetes and insulin on hepatic delta 6 desaturase gene expression. Biochem Biophy Res Comm 2001; 283:323-6.

60. Chen XJ, Mao HL, Ma XM, Liu JX. Effects of dietary corn oil and vitamin E supplementation on fatty acid profiles and expression of acetyl CoA carboxylase and stearoyl-CoA desaturase gene in Hu sheep. Animal Sci J 2010; 81: 165-71.

61. Frenkel AL, Canetti L, Halpern Z. Effects of nutritional lipids on diabetic manifestations and $\Delta 6$ desaturase mRNA level in streptozotocin treated mice. Nutr Res 2004; 24: 303-12.

62. Comin D, Gazarini L, Zanoni JN, Milani H, de Oliveira RM. Vitamin E improves learning performance and changes the expression of nitric oxide-producing neurons in the brains of diabetic rats. Behav Brain Res 2010; 210: 38-45.
63. Jain $A B$, Jain VA. Vitamin $E$, its beneficial role in diabetes mellitus (DM) and its complications. J Clin Diagn Res $2012 ; 6: 1624-8$.

64. Opara E.C. Oxidative stress, micronutrients, diabetes mellitus and its complications. J R Soc Promot Health 2002; 122: 28-34.

65. Maxfield FR, Tabas I. Role of cholesterol and lipid organization in disease. Nature 2005; 438: 612-21.

66. Noyan T, Balahoroğlu R, Kömöroğlu U. Diyabetik sıçanlarda insülinle kombine edilmiş $A, E$, ve $C$ vitamini tedavisinin antioksidan enzimler üzerine etkileri. Türk Klinik Biyokimya Dergisi 2004; 2: 113-9.

67. Shin S, Ku Y, Babu N, Singh M. Erythrocyte deformability and its variation in diabetes mellitus. Indian J Exp Biol 2007; 45:121-8.

68. Vahalkar GS, Haldankar VA. RBC membrane composition in insulin dependent diabetes mellitus in context of oxidative stress. Indian J Clin Biochem 2008; 23:223-6.

69. O'Meara NM, Devery RA, Owens D, Collins PB, Johnson $\mathrm{AH}$, Tomkin GH. Cholesterol metabolism in alloxaninduced diabetic rabbits. Diabetes 1990; 39: 626-33.

70. Lovejoy JC, Most MM, Lefevre M, Greenway FL, Rood JC. Effect of diets enriched in almonds on insulin action and serum lipids in adults with normal glucose tolerance or type 2 diabetes. Am J Clin Nutr 2002; 76:1000-6.

71. Alhazzaa R, Oen JJJ, Sinclair AJ. Dietary phytosterols modify the sterols and fatty acid profile in a tissuespecific pattern. J Func Foods 2013; 5:829-37. 